\title{
Kepemimpinan Spiritual dalam Lembaga Pendidikan: Analisis Maqasid Syariah
}

\author{
Nur Ita A'ini Qudwatal Millah', Far'ia ${ }^{2}$ \\ ${ }^{1}$ FITK, Universitas Islam Negeri Sunan Kalijaga Yogyakarta, Indonesia \\ ${ }^{2}$ FITK, Universitas Islam Negeri Sunan Kalijaga Yogyakarta, Indonesia \\ ${ }^{1}$ nuritaaini2095@gmail.com \\ 2fariayaya1312@gmail.com
}

\begin{abstract}
Abstrak:
Kepemimpinan di sebuah lembaga pendidikan merupakan salah satu faktor penentu keberhasilan sebuah lembaga pendidikan. Melalui sistem dan pola kepemimpinan yang baik, lembaga pendidikan akan mampu mengetahui kemana arah yang hendak ia tuju dan capai secara jelas. Kecerdasan spiritual dibutuhkan bagi seorang pemimpin untuk memimpin sebuah lembaga pendidikan, utamanya lembaga pendidikan Islam. Dalam ruang lingkup kepemimpinan yang berlandaskan nilai-nilai spiritual, yang menjadi orientasi dari segala aktivitasnya ialah sebagai manifestasi ibadah serta sarana pengabdian kepada Tuhan. Oleh karenanya, dalam jurnal tersebut membahas tentang konsep kepemimpinan spiritual dalam lembaga pendidikan Islam perspektif Maqashid Syariah dari segi dharuriyyatnya dimulai dari sisi hifdz al-din, hifdz al-nafs, hifdz al-aql, hifdz al-nasl dan hifdz al-mal serta implementasinya di Program Studi Manajemen Dakwah UIN Sunan Kalijaga Yogyakarta. Penelitian ini menggunakan metode studi deskriptif kualitatif. Teknik pengumpulan data menggunakan observasi, wawancara serta dokumentasi. Hasil penelitian menunjukkan bahwa ketua jurusan di program studi ini memiliki program utama yaitu dalam pendidikan dan pelatihan sebagai bagian dari pengembangan kepemimpinan spiritual. Melalui hal ini pula, ketua jurusan serta dosen tidak sekadar menggugurkan kewajiban administrasi semata yakni menjalankan proses pembelajaran, tetapi juga sebagai sarana pengabdian kepada Allah. Selain itu, kepemimpinan spiritual ditunjukkan melalui upaya peneladanan terhadap sifat-sifat Rasulullah, yakni siddiq, amanah, tabligh, dan fathanah serta berbagai bentuk kebijakan yang diterapkan oleh Ketua Jurusan bertujuan untuk mencapai kemaslahatan bersama.
\end{abstract}

Kata Kunci: Kepemimpinan Spiritual, Lembaga Pendidikan, Maqashid Syariah.

\begin{abstract}
:
Leadership in an educational institution is one of the determining factors in the success of an educational institution. Through a good system and pattern of leadership, educational institutions will be able to know where they want to go and reach clearly. Spiritual intelligence is needed for a leader to lead an educational institution, especially Islamic educational institutions. In the scope of leadership based on spiritual values, the orientation of all its activities is as a manifestation of worship and a means of devotion to God. Therefore, the journal discusses the concept of spiritual leadership in Islamic educational institutions
\end{abstract}


Maqashid Sharia perspective in terms of dharuriyyat starting from the side of hifdz al-din, hifdz al-nafs, hifdz al-aql, hifdz al-nasl and hifdz al-mal and its implementation in the Da'wah Management Study Program of UIN Sunan Kalijaga Yogyakarta. This research uses descriptive qualitative study methods. Data collection techniques using observation, interviews and documentation. The results showed that the head of the department in this study program had a main program in education and training as part of the development of spiritual leadership. Through this case, the head of the department and the lecturer do not simply abort the administrative obligations, namely to carry out the learning process, but also as a means of devotion to God. In addition, spiritual leadership is demonstrated through exemplary efforts to the characteristics of the Prophet, namely siddiq, amanah, tabligh, and fathanah as well as various forms of policies implemented by the Chair of the Department aiming to achieve mutual benefit.

Keywords: Spiritual Leadership, Educational Institutions, Maqashid Sharia.

\section{Pendahuluan}

Seyogyanya, dalam setiap lembaga pendidikan sangatlah membutuhkan suatu sistem yang terstruktur dan sistematis agar lembaga pendidikan tersebut dapat berjalan secara maksimal. Dalam sistem pendidikan terdapat beberapa unsur yang saling berkaitan yakni pemimpin, tenaga pendidik dan kependidikan, serta adanya peserta didik. Ketiganya saling berkaitan demi berjalannya sebuah lembaga pendidikan.

Selain peran tenaga pendidik dan kependidikan, terdapat peran penting yang tidak dapat diabaikan ialah peran sebagai seorang pemimpin sehingga diharapkan seorang pemimpin tersebut haruslah paham mengenai kondisi yang dialami lembaga yang dipimpinnya, karena menjadi penentu kebijakan yang akan ditetapkannya. Pemimpin merupakan sosok figur yang menjadi penentu sebuah keputusan serta kebijakan yang akan diambil dalam suatu lembaga pendidikan.

Pemimpin juga perlu mempunyai berbagai kecerdasan dalam menjalankan tugasnya. Kecerdasan seorang pemimpin dapat berupa kecerdasan intelektual (IQ), kecerdasan emosional (EQ), serta kecerdasan spiritual (SQ). Dari kecerdasan tersebut, terdapat dalah satu kecerdasan yang tidak boleh diabaikan perannya oleh seorang pemimpin di lembaga pendidikan Islam yaitu kecerdasan spiritual.

Kecerdasan spiritual tersebut sangatlah dibutuhkan oleh seorang pemimpin dalam memimpin serta mengarahkan sebuah lembaga pendidikan, terutama pada lembaga pendidikan Islam. Ketika seorang pemimpin memiliki kecerdasan spiritual yang baik, maka segala aktivitas kepemimpinannya akan dijalankan sesuai prinsip dan nilai-nilai spiritualitas. Dalam ruang lingkupnya, kepemimpinan spiritual ini lebih berorientasi sebagai sarana beribadah dan bentuk pengabdian kepada Tuhan. Dalam kepemimpinan ini juga terdapat berbagai kebijakan 
yang di tetapkan selalu berlandaskan pada prinsip dan nilai-nilai dalam ajaran islam, sehingga kebijakan yang dihasilkan akan bermuara pada kemashlahatan (Maqashid Syari'ah) bagi semua stakeholder pada lembaga pendidikan yang dipimpinnya.

Al-Quran sebagai sumber ajaran Islam tidak seluruhnya memuat aturan rinci tentang ibadah, hanya saja sebagian masalah dalam Islam hanyalah diberikan dasar dan prinsipnya saja dalam Al-Qur'an. Hal ini terbukti pada 368 ayat yang ada dalam Al-Quran berkaitan dengan aspek-aspek hukum. ${ }^{1}$ Dasar-dasar hukum tersebut dijelaskan lebih rinci dengan sabda Nabi Muhammad saw melalui hadits-haditsnya. Allah swt sebagai pembuat syari'at tentulah tidak menciptakan suatu hukum atau aturan di muka bumi ini tanpa adanya tujuan dan maksud begitu saja, melainkan hukum dan aturan tersebut diciptakan untuk mewujudkan kemaslahatan hamba-Nya sekaligus menghindari kemafsadatan dunia maupun akhirat. Berkaitan hal tersebut, Allah swt menetapkan perintah dan larangan yang terdapat dalam Al-Quran dan Hadits bahwa segala sesuatu tentunya memiliki tujuan tertentu dan tiada yang sia-sia, sehingga inti dari tujuan syari'at (hukum) yang dikenal maqashid syari'ah bertujuan mendatangkan kemaslahatan dan menolak kemafsadatan.

Kepemimpian spiritual dalam lembaga pendidikan perspektif maqashid syari'ah ialah kepemimpinan yang membawa dimensi keduniawian menuju dimensi spiritual (keilahian) serta mempertimbangkan kemaslahatan bersama. Dalam Islam, sifat seorang pemimpin dapat mencontoh sifat seorang Nabi sebagai uswatun hasanah. Artinya perilaku keseharian Nabi Muhammad saw, terutama yang berkaitan tentang cara beliau memimpin umatnya merupakan role model ideal tentang kepemimpinan spiritual termasuk dalam sebuah lembaga pendidikan.

\section{Metode Penelitian}

Adapun dalam penelitian ini menggunakan jenis pendekatan kualitatif deskriptif dengan tujuan mengambil suatu kesimpulan secara mendalam dari suatu realita yang ada di lapangan. Artinya penelitian kualitatif merupakan kegiatan sistematis untuk menemukan informasi baru dari lapangan, bukan untuk menguji teori. ${ }^{2}$ Dalam artikel ini, teknik pengumpulan data yang digunakan ialah observasi, wawancara dan dokumentasi. Teknik observasi digunakan untuk menemukan tingkah laku nonverbal atau mengamati sebuah peristiwa. Artinya bahwa bentuk obervasi di mana pengamat tidak terlibat langsung dalam

\footnotetext{
${ }^{1}$ La Jamaa, “Dimensi Ilahi dan Dimensi Insani dalam Maqashid al-Syari'ah”. Jurnal Asy-Syir'ah Ilmu Syari'ah dan Hukum, Vol 45, No. II, Juli-Desember 2011, hlm. 1251-1270.

${ }^{2}$ Andi Prastowo, Metode Penelitian Kualitatif, (Yogyakarta: Ar-Ruzz Media, 2014), hlm. 21.
} 
kegiatan kelompok tersebut. ${ }^{3}$ Wawancara adalah bentuk komunikasi antara dua orang atau lebih dan melibatkan seseorang yang ingin memperoleh informasi dari seorang dengan mengajukan pertanyaan-pertanyaan berdasarkan tujuan tertentu. ${ }^{4}$ Dokumentasi berupa catatan narasumber terkait informasi yang diperlukan oleh peneliti yang sesuai dengan fokus penelitian. Dokumen itu dapat berbentuk teks tertulis, artefacts, gambar dan foto. ${ }^{5}$

\section{Pengertian Kepemimpinan Spiritual}

Membahas mengenai kepemimpinan, tentunya selalu menjadi hak menarik untuk dikaji. Berkaitan hal tersebut, terdapat beberapa definisi yang dikemukakan oleh para ahli mengenai kepemimpinan. Robbins mendefiniskan kepemimpinan sebagai kemampuan dalam mempengaruhi suatu kelompok menuju pada pencapaian tujuan. ${ }^{6}$ Sedangkan Greenberg dan Baron mendefinisikan kepemimpinan ialah proses dimana satu individu dapat memengaruhi anggota kelompok lainnya untuk tercapainya tujuan kelompok atau organisasional yang didefinisikan. $^{7}$

Senada hal tersebut, Kreitnet dan Kinicki mendefinisikan kepemimpinan sebagai proses individu dalam memengaruhi sekelompok individual agar tercapainya tujuan bersama. Lebih singkatnya lagi dikemukakan oleh Newstrom bahwasanya kepemimpinan merupakan suatu proses memengaruhi dan mendukung orang lain untuk bekerja secara antusias agar tercapainya sasaran. $^{8}$

Dari beberapa pendapat para ahli tersebut, dapat disimpulkan bahwa kepemimpinan ialah kemampuan meyakinkan orang lain agar mau bekerja sama di bawah pimpinannya sebagai sebuah tim untuk mencapai tujuan tertentu. ${ }^{9}$ Oleh karenanya dalam mencapai tujuan tersebut, seorang pemimpin perlu memiliki berbagai macam kemampuan dan kecerdasan, salah satunya yang dikenal sebagai kecerdasan spiritual. Tindakan yang dimaksud disini tidak hanya sebatas tindakan formal semata akan tetapi lebih kepada sebuah bentuk pengabdian kepada Tuhan.

${ }^{3}$ A. Muri Yusuf, Metode Penelitian Kuantitatif, Kualitatif, dan Penelitian Gabungan, (Jakarta: Kencana, 2015), hlm. 384.

${ }^{4}$ Deddy Mulyana, Metodologi Penelitian Kualitatif, (Bandung: PT Remaja Rosdakarya, 2010), hlm. 180.

${ }^{5}$ A. Muri Yusuf, Metode Penelitian Kuantitatif, Kualitatif, dan Penelitian Gabungan, (Jakarta: Kencana, 2015), hlm. 391.

${ }^{6}$ Wibowo, Kepemimpinan: Pemahaman Dasar, Pandangan Konvensional, Gagasan Kontemporer ( Jakarta: Rajawali Pers, 2016), hlm. 3.

${ }^{7}$ Ibid.

${ }^{8}$ Ibid.

9 Veithzal Rivai dan Arviyan Arifin, Islamic Leadership: Membangun Superleadership Melalui Kecerdasan Spiritual (Jakarta: Bumi Aksara, 2009), hlm. 106. 
Kecerdasan spiritual berlandaskan oleh kesadaran rohaniah, yakni kesadaran bahwa kehidupan bukan semata kehidupan fisik yang bersifat materi dan akan berakhir pada kematian. ${ }^{10}$ Akan tetapi, keyakinan lain bahwa kehidupan manusia tidaklah terhenti seiring dengan berakhirnya kehidupan di dunia ini. Karena setelah kematian, masih ada kehidupan lain yang harus dijalani sebagai bentuk pertanggungjawaban kehidupan selama di dunia. Kesadaran itulah yang mendorong seseorang untuk melakukan yang terbaik selama masih diberi kesempatan.

Merujuk dari berbagai sumber di atas, maka dapat disimpulkan bahwa kepemimpinan spiritual ialah cara mempengaruhi orang lain guna mencapai suatu tujuan tertentu melalui perbuatan berdasarkan prinsip dan nilai yang telah dicontohkan oleh Nabi Muhammad saw.

\section{Karakteristik Kepemimpinan Spiritual}

Nabi Muhammad saw merupakan sosok figur teladan dan sosok ideal sebagai seorang pemimpin. Perkataan, perbuatan, dan ketetapan Nabi Muhammad saw menjadi salah satu sumber yang dijadikan pedoman bagi seluruh umat Islam dalam menjalani aktivitas kehidupannya. Allah swt telah memberikan gambaran mengenai figur seorang Nabi Muhammad saw sebagaimana tertuang dalam Q.S Al-ahzab (33) : 21. Ayat ini mengajarkan kepada kita bahwa pada diri seorang Nabi terdapat teladan dan contoh yang baik untuk ditiru oleh seluruh umat dalam menjalankan kehidupannya. Kehidupan sehari-hari beliau menjadi sebuah inspirasi bagi siapapun untuk menjalankan aktivitas kehidupannya, termasuk ketika menjadi seorang pemimpin.

Adapun beberapa ciri-ciri yang menggambarkan kepemimpinan Islam ialah sebagai berikut : ${ }^{11}$

a. Setia, bahwasanya seorang pemimpin dan orang yang dipimpin tentunya haruslah mengabdi kepada Allah swt.

b. Terkait pada tujuan, ketika seorang pemimpin diberikan amanah dalam tujuan berorganisasi bukanlah hanya berdasar pada kepentingan kelompok saja, akan tetapi juga dalam ruang lingkup tujuan Islam yang lebih luas.

c. Menjunjung tinggi syari'at dan akhlak Islam, bahwasanya seorang pemimpin merasa terkait dengan peraturan Islam, serta tidak menyimpang dari syari'at.

\footnotetext{
${ }^{10}$ Subarto Zaini, Leadership in Action: Pembelajaran dari Para Maestro (Jakarta: PT. Elex Media Komputindo, 2011), hlm. 266.

${ }^{11}$ Veithzal Rivai dan Arviyan Arifin, Islamic Leadership:Membangun Superleader..., hlm. 136-139.
} 
d. Memegang teguh amanah, bahwasanya seorang pemimpin ketika menerima kekuasaan haruslah disertai tanggung jawab serta selalu menunjukkan sikap baik kepada orang yang dipimpinnya.

e. Tidak sombong, bahwasanya selalu menyadari hanya Alllah swt lah yang Maha Besar, sehingga kerendahan hati dalam memimpin menjadi salah satu ciri kepemimpinan yang patut dikembangkan.

f. Disipin, konsisten, konsekuen menjadi ciri kepemimpinan dalam Islam dalam segala tindakan dan perbuatan seorang pemimpin. Seorang pemimpin yang profesional akan senantiasa memegang teguh terhadap janji, ucapan serta perbuatan yang dilakukan, karena menyadari bahwa Allah swt mengetahui semua yang ia lakukan meskipun ia berusaha menyembunyikannya.

\section{Prinsip-prinsip Kepemimpinan Spiritual}

Mengenai prinsip kepemimpinan spiritual, Ismail Noor mengemukakan terdapat tiga hal yang menjadi pegangan seorang pemimpin, yakni: Syura' (Musyawarah), Adl bi al-Qisth (keadilan dengan kesetaraan) dan Uswah (suri tauladan). ${ }^{12}$ Prinsip tersebut dijabarkan sebagai berikut:

\section{Syura' (Musyawarah)}

Nabi Muhammad saw merupakan sosok teladan yang sangat menjunjung tinggi musyawarah. Hal ini sejalan dengan perintah Allah untuk melaksanakan musyawarah dalam Alquran Surah Ali Imran (3) : 159. Ayat ini menjelaskan tentang pentingnya bermusyawarah. Musyawarah sebagai salah satu bentuk akhlak terpuji dikarenakan apabila seorang penyeru kebaikan / peringatan enggan melaksanakan musyawarah bahkan berlaku kasar dan keras hati, maka orang-orang yang hendak diberi peringatan akan menjauhkan diri. Realitanya Rasulullah tidak segan untuk meminta pendapat dari para sahabatnya yaitu kaum muslimin yang hidup di zaman Nabi dan Khulafaurrasyidin yang menikmati kebebasan berpendapat dan bermusyawarah serta menyampaikan pendapat mereka dihadapan Nabi. ${ }^{13}$

Demikian halnya menjadi seorang pemimpin di sebuah lembaga pendidikan, seyogyanya pimpinan haruslah mengedepankan prinsip musyawarah, karena musyawarah

\footnotetext{
${ }^{12}$ Syamsudin, Tesis Magister: “Kepemimpinan Profetik: Telaah Kepemimpinan Umar bin Khattab dan Umar bin Abdul Aziz”, ( Malang: UIN Maulana Malik Ibrahim, 2015), hlm. 56.

${ }^{13}$ Ahmad Muhammad Al-Hufy, Akhlak Nabi Muhammad SAW: Keluhuran dan Kemuliannya, Alih Bahasa. Masdar Hilmy (Bandung: Gema Risalah Press, 1995), hlm. 423.
} 
sangatlah dibutuhkan untuk mendengarkan aspirasi dari para bawahan maupun stakeholder pendidikan sebagai bentuk upaya perbaikan pengelolaan pendidikan.

\section{Adl- bi al-Qisth (Keadilan dan Kesetaraan)}

Sikap Nabi Muhammad saw sangatlah menjunjung tinggi prinsip keadilan yang terlihat dari kisah seorang perempuan dari Bani Makhzum ketika terlibat dalam kasus pencurian. Nabi Muhammad dengan tegas mengatakan sebagaimana hadis yang diriwayatkan oleh Aisyah ra bahwasanya:

"Sesungguhnya telah binasa orang-orang sebelum kalian disebabkan apabila ada salah seorang yang terpandang di antara mereka mencuri, mereka membiarkannya begitu saja. Akan tetapi, jika salah seorang daripada mereka yang lemah (rakyat biasa) mencuri, mereka menegakkan hukum baginya. Demi Allah, jika saja Fatimah puteri Muhammad mencuri, maka aku sendiri yang akan memotong tangannya."14

Peristiwa di atas merupakan bentuk penggambaran bahwa Nabi Muhammad saw sangatlah menjunjung tinggi prinsip keadilan. Beliau tidak segan dalam memberikan hukuman secara objektif kepada siapa saja apabila orang tersebut memang melakukan kesalahan, sekalipun itu putri beliau tercinta, Fatimah ra. Peristiwa ini memberikan sebuah pelajaran bahwasanya seorang pemimpin hendaknya menjadi seorang penegak keadilan.

Sama halnya ketika menjadi seorang pemimpin yang memegang prinsip kepemimpinan spiritual tentu dalam melaksanakan tugas kepemimpinannya dijalankan dengan menjunjung tinggi keadilan. Dalam ilmu manajemen terdapat konsep yang biasa disebut reward and punishment atau penghargaan dan hukuman. Seorang pemimpin di sebuah lembaga pendidikan Islam harus menjalankan konsep pemberiaan penghargaan dan hukuman secara objektif kepada siapa saja yang memang berhak menerima penghargaan atau teguran tersebut, tanpa memandang apakah siapapun dan berasal dari manapun ia.

\section{Uswah (Suri Tauladan)}

Salah satu faktor kesuksesan lainnya dalam kepemimpinan pendidikan Islam ialah mewariskan keteladanan. Dalam kesehariannya, Rasulullāh saw selalu memberikan suri tauladan yang baik kepada umatnya. Rasulullah saw ialah al-Qur'an yang hidup yang mana

\footnotetext{
${ }^{14}$ Suraya Ishak, Model Kepemimpinan Etika Berlandas Sirah Nabi Muhammad SAW., Jurnal Hadhari 3, 2 2011, Universiti Kebangsaan Malaysia, hlm. 32.
} 
pada diri Rasulullah saw tercermin semua ajaran al-Quran dalam bentuk nyata perilaku kesehariannya.

Diriwayatkan oleh Bukhari dari Al Bara' bin Azib berkata: bahwa Rasulullah saw saat perang Khandaq ikut memindahkan pasir sehingga perutnya penuh dengan debu. ${ }^{15}$ Sebagai seorang pemimpin, Rasulullah tidak segan untuk melakukan hal-hal kecil yang dapat menjadi contoh bagi para sahabatnya. Jabatan yang beliau punya, tidak serta merta membuat beliau enggan melakukan hal yang boleh jadi cukup dilakukan para sahabatnya. Rasulullah mengajarkan bahwasanya menjadi seorang pemimpin, hendaknya dapat memberikan teladan berupa tindakan, yang tidak hanya melalui sebuah ucapan. Dalam ruang lingkup kepemimpinan dalam lembaga pendidikan, seorang pemimpin dapat memberikan keteladanan dengan hal seperti hadir tepat waktu, berpenampilan rapi, bersikap ramah kepada semua orang dan bertutur kata yang baik.

\section{Konsep Maqashid Syariah}

Secara etimologi, مقاصد الثريعة (maqashid al-syari'ah) merupakan istilah gabungan dari

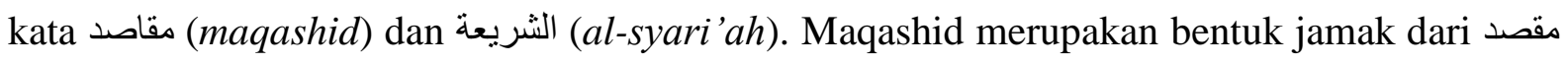
(maqshad), قصد (qashd). Ia merupakan derivasi dari kata kerja قصد-يقصد (qashada-yaqshidu) dengan beragam makna, seperti menuju suatu arah, tujuan, tengah-tengah, adil tidak melampaui batas, serta tujuan akhir. ${ }^{16}$ Istilah ini dapat disamakan dengan istilah 'ends' dalam bahasa Inggris, 'telos' dalam bahasa Yunani, 'finalite' dalam bahasa Perancis, atau 'Zweck' dalam bahasa Jerman. ${ }^{17}$ Adapun syari'ah secara etimologi berasal dari kata شرع-عشرع (syara'ayasyra'u) yang berarti membuat syari'at atau undang-undang, menerangkan serta menyatakan. ${ }^{18}$ Maqasid hukum Islam ialah sasaran atau maksud di balik hukum yang merupakan pernyataan alternatif untuk مصالح (masalih) atau kemaslahatan. ${ }^{19}$ Menurut Ibnu Asyur, inti dari maqashid syari'ah ialah tercapainya kemaslahatan umat yang sebesar-besarnya,

\footnotetext{
${ }^{15}$ E.Mulyasa, Manajemen dan Kepemimpinan Kepala Sekolah (Jakarta: Bumi Aksara, 2012), hlm. 27.

${ }^{16}$ Ahmad Imam Mawardi, Fiqh Minoritas (Fiqh Al-Aqalliyat dan Evolusi Maqashid Al-Syari'ah dari Konsep ke Pendekatan), (Yogyakarta: PT LKiS Printing Cemerlang, 2012), hlm 178.

${ }^{17}$ Jaser Auda, Al-Maqasid Untuk Pemula, (Yogyakarta: SUKA-Press UIN Sunan Kalijaga, 2013), hlm 6.

18 Sandy Rizki Febriadi, “Aplikasi Maqashid Syariah Dalam Bidang Perbankan Syariah”, Jurnal Amwaluna, Vol. 1, No 2, Juli 2017, 231-245.

${ }^{19}$ Jaser Auda, Membumikan Hukum Islam Melalui Maqasid Syariah, (Bandung: PT Mizan Pustaka, 2015), hlm 33 .
} 
karena tujuan penetapan hukum dalam Islam ialah untuk menciptakan kemaslahatan dalam rangka memelihara tujuan syara'. ${ }^{20}$

Sedangkan secara terminologi, terdapat beberapa pengertian tentang maqashid alsyari'ah yang dikemukakan oleh beberapa ulama terdahulu sebagai berikut:

a. Imam al-Ghazali

$$
\text { فر عاية المقاصد عبارة حاوية للابقاء ودفع القواطع و التحصيل على سبيل اللابتداء. }
$$

"Penjagaan terhadap maksud dan tujuan syari'ah adalah upaya mendasar untuk bertahan hidup, menahan faktor-faktor kerusakan dan mendorong terjadinya kesejahteraan". ${ }^{21}$

b. Imam al-Syathibi:

المقاصد قسمان: احدهما يرجع الى قصد الثنارع, و الأخرير جع الي قصد المكلف. هذه الثريعة وضعت لتحقيق مقاصد الثارع في قيام مصالحهم في الدين و الدنيامعا

"Al-Maqashid terbagi menjadi dua: yang pertama berkaitan dengan maksud Tuhan selaku pembuat syari'ah, dan kedua, berkaitan dengan maksud mukallaf. Syari'at ini bertujuan untuk mewujudkan kemaslahatan manusia di dunia dan di akhirat"22

Dari beberapa pendapat ulama di atas, dapat disimpulkan bahwasanya maqashid syari'ah merupakan tujuan umum yang ingin diraih dan diwujudkan dalam kehidupan sebagai salah satu konsep penting dalam kajian hukum Islam. Adapun inti dari maqashid syari'ah tersebut untuk mewujudkan kebaikan sekaligus menghindari keburukan, menarik kemaslahatan dan menolak kemafsadatan. Oleh karenanya, istilah sepadan dengan maqashid syariah tersebut ialah maslahah, dikarenakan dalam penetapan hukum Islam tentunya harus bermuara kepada kemaslahatan dunia yang berimbas kepada kebaikan akhirat.

Secara historis, Imam al-Haramain al-Juwaini dikatakan sebagai ahli ushul pertama yang menekankan pentingnya pemahaman mengenai maqashid syari'ah dalam menetapkan hukum Islam. Secara tegas, ia mengatakan bahwa seorang tidak dapat dikatakan mampu menetapkan suatu hukum dalam Islam sebelum ia paham secara benar tujuan Allah mengeluarkan perintah dan larangan-Nya.

Adapun kemaslahatan dikategorikan menjadi dua, yaitu kemaslahatan dharuriyyat (inti/pokok) yang berada dalam urutan paling atas dan kemaslahatan ghairu dharuriyyah (bukan kemaslahatan pokok) yang tergolong penting setelah terpenuhinya kemaslahatan inti. ${ }^{23}$

\footnotetext{
${ }^{20}$ Nispan Rahmi, "Maqasid Al Syari’ah: Melacak Gagasan Awal”. Jurnal Ilmu Hukum dan Pemikiran Maqasid al-Syari'ah, Vol 17, No 2, Desember 2017, 161.

${ }^{21}$ Fauzia dan Riyadi A, Prinsip Dasar Ekonomi Islam Perspektif Maqashid Al-Syari'ah, (Jakarta: Kencana Prenadamedia Group, 2014), hlm 41.

${ }^{22}$ Ibid., hlm. 44.

${ }^{23}$ Ahmad Al-Mursi Jauhar, Maqashid Syariah (Terj. Khikmawati- Kuwais), (Jakarta: Amzah, 2009) hlm XV.
} 
Hal ini dipertegas pada prinsipnya Al-Juwaini yang dibedakan menjadi tiga kategori yaitu: peringkat dlarûriyyât (primer), hajiyyât (sekunder) dan tahsiniyyât (tersier). ${ }^{24}$ Pemikiran alJuwaini tersebut dikembangkan oleh muridnya, al-Ghazali. Kelima maslahat ini berada pada tingkat berbeda sesuai dengan skala prioritas kemaslahatan tersebut yaitu:

\section{Pemeliharaan Aspek Ad-Dharuriyyat (primer)}

Dalam pemeliharaannya, aspek ad-dharuriyyat (primer) merupakan suatu yang mestinya ada demi terwujudnya kemaslahatan agama. Apabila hal ini tidak ada, maka kemaslahatan dunia bahkan akhirat juga akan hilang sehingga yang muncul justru kerusakan dan musnahnya kehidupan. Dharuriyyat menunjukkan kebutuhan dasar ataupun primer yang harus selalu ada dalam kehidupan manusia. Dharuriyyat menurut al-Ghazali dapat dicapai dengan cara menjaga lima kebutuhan pokok manusia dalam khazanah ushul fiqh disebut $a l$ kulliyat al-khams ${ }^{25}$ dalam kehidupannya, yaitu memelihara agama (al-din), jiwa (al-nafs), akal $(a l-a q l)$, keturunan $(a l-n a s l)$, dan harta $(a l-m a l)^{26}$ sehingga dalam pelestarian kelima hal tersebut merupakan suatu yang mutlak dilakukan. Apabila kelima hal tersebut dapat terwujud, maka akan tercapai suatu kehidupan yang mulia dan sejahtera baik di dunia maupun akhirat. Tercukupinya kebutuhan akan memberikan dampak maslahah, karena kelima hal tersebut haruslah terpenuhi oleh masing-masing individu dan apabila tidak dilaksanakan maka akan berdampak negatif terhadap kehidupan seseorang.

\section{Pemeliharaan Aspek Al-Hajiyyat (sekunder)}

Tahapan pemeliharaan berikutnya dari maqashid syari'ah ini ialah al-hajiyyat yang dimaknai sebagai hal yang perannya sangatlah dibutuhkan untuk mewujudkan kemudahan dan menghilangkan kesulitan, sehingga jika al-hajiyyat tidak ada maka seseorang tersebut tidak akan tertimpa kerusakan yang diakibatkan tidak akan mengganggu kemaslahatan umum. Jika sesuatu ini tidak ada, maka ia tidak akan menimbulkan kerusakan atau kematian hanya saja mengakibatkan masyaqqah atau kesempitan. Sebagaimana contoh, dalam masalah ibadah adanya rukhsah shalat jama' dan qashar bagi musafir. Oleh karenanya, al-hajiyyat juga dimaknai sebagai pemenuhan kebutuhan sekunder ataupun sebagai pelengkap dalam penunjang kehidupan manusia. ${ }^{27}$

\footnotetext{
${ }^{24}$ Ali Mutakin, "Teori Maqashid Al Syariah dan Hubungannya dengan Metode Istinbath Hukum”, Jurnal Ilmu Hukum, Vol 19, No 3, Agustus 2017, 547-570.

${ }^{25}$ Halil Thahir, Ijtihad Maqasidi (Rekonstruksi Hukum Islam Berbasis Interkoneksitas Maslahah, (Yogyakarta: PT LKiS Printing Cemerlang, 2015) hlm 1.

${ }^{26}$ Ghofar Shidiq, "Teori Maqashid Al-Syariah dalam Hukum Islam”. Jurnal Majalah Ilmiah Sultan Agung, Vol 44, No 118, Juni-Agustus 2009, hlm. 124.

${ }^{27}$ Fauzia dan Riyadi A, Prinsip Dasar Ekonomi Islam, .... hlm 41.
} 


\section{Pemeliharaan Aspek At-Tahsiniyat (tersier)}

Tahapan terakhir dari maqashid syari'ah ialah at-tahsiniyat yang dimaknai melakukan kebiasaan yang baik serta menghindari hal buruk sesuai dengan apa yang diketahui oleh akal sehat. Seseorang ketika menginjak at-tahsiniyat berarti telah mencapai keadaan dimana ia dapat memenuhi suatu kebutuhan yang dapat meningkatkan kepuasaan dalam hidupnya. Oleh karenanya, apabila sesuatu tersebut tidaklah ada, maka tidak akan menimbulkan kerusakan ataupun jika sesuatu tersebut hilang maka tidak akan menimbulkan masyaqqah dalam melaksanakannya, hanya saja dinilai tidak pantas atau tidak layak menurut ukuran tatakrama dan kesopanan. Contohnya dalam menutup aurat dengan pakaian yang bersih dan bagus, larangan israf, cara makan dan minum yang baik. Keadaan ini merupakan pelengkap hidup manusia, sehingga manusia dapat merasakan kenyamanan hidup. ${ }^{28}$ At-tahsiniyat juga biasa dikenali dengan kebutuhan tersier atau sebagai pelengkap dari kebutuhan primer.

\section{Kepemimpinan Spiritual Perspektif Maqashid Syari'ah di Program Studi Manajemen Dakwah UIN Sunan Kalijaga Yogyakarta}

Program Studi Manajemen Dakwah yang berada di bawah naungan Fakultas Dakwah dan Komunikasi merupakan salah satu prodi yang berada di Universitas Islam Negeri Sunan Kalijaga Yogyakarta. Prodi ini merupakan salah satu prodi yang terakreditasi A di UIN Sunan Kalijaga Yogyakarta. Dalam prodi ini memiliki konsentrasi pada tiga bidang utama, yakni (1) Manajemen Sumber Daya Manusia (SDM), (2) Manajemen Lembaga Keuangan Islam, dan (3) Manajemen Haji, Umroh, dan Wisata Religi lainnya.

Program Studi Manajemen Dakwah UIN Sunan Kalijaga Yogyakarta ini berada di bawah pimpinan Bapak Drs. Rosyid Ridla, M.Si selaku Ketua Jurusan Program Studi Manajemen Dakwah. Dalam kepemimpinannya, beliau menerapkan beberapa aspek terkait kepemimpinan spiritual dalam lembaga pendidikan khususnya di lingkungan kampus. Prodi ini memiliki program pembinaan spiritual atau keagamaan rutin pada setiap harinya.

Adapun keunggulan Prodi Manajemen Dakwah dibandingkan prodi lainnya yaitu memiliki bimbingan karir dengan konsentrasi yang berbeda-beda. Dalam kepemimpinannya, ketua jurusan senantiasa menerapkan aspek terkait kepemimpinan spiritual di lingkungan kampus yang rutin dilaksanakan setiap hari Jum'at di setiap bulannya sebelum shalat Jum'at

\footnotetext{
${ }^{28}$ Sandy Rizki Febriadi, “Aplikasi Maqashid Syariah Dalam Bidang Perbankan Syariah”, Jurnal Amwaluna, Vol. 1, No 2, Juli 2017, hlm 240.
} 
dimulai. Dalam kegiatan ini, ketua jurusan menyampaikan beberapa wejangan serta motivasi keagamaan yang bersumber dari ayat-ayat Al-Qur'an kepada para dosen serta mahasiswa.

Dalam program studi ini, memiliki agenda rutin berupa koordinasi berupa rapat dalam memantau dan melihat perkembangan yang terjadi pada program studi. Dalam setiap kesempatan memimpin rapat, ketua jurusan selalu membuka kegiatan rapat dan mengkaitkannya dengan sebuah materi yang berisi kisah motivasi dan cerita inspirasi dari tokoh cendekiawan muslim. Hal ini dilakukan juga sebagai bentuk pembinaan spiritual keagamaan bagi para dosen di lingkungan Program Studi Manajemen Dakwah UIN Sunan Kalijaga Yogyakarta. Salah satu hal yang selalu ditegaskan oleh ketua jurusan ialah tentang tugas dan fungsi dosen. Ketua Jurusan senantiasa menekankan kepada para dosen agar tidak hanya sebagai seorang pendidik yang menyampaikan mata kuliah semata, serta menjadi sebagai seorang pendidik yang menanamkan nilai moral yang baik kepada para mahasiswa dengan harapan agar mahasiswa memiliki karakter religiusitas baik.

Selain itu, salah satu aspek penting yang harus dimiliki seorang pemimpin disini atau sebagai ketua jurusan ialah kemampuan meningkatkan hubungan melalui jalinan komunikasi yang fleksibel. Dalam aktivitas kesehariannya, baik di lingkungan kampus maupun di luar sekolah, ketua jurusan Program Studi Manajemen Dakwah UIN Sunan Kalijaga Yogyakarta menerapkan dan menunjukkan sebuah proses komunikasi yang terbuka. Ketua Jurusan tidak perlu menutup diri bagi para dosen maupun mahasiswa dalam penyampaian aspirasi ataupun masukan untuk kemajuan perkembangan program studi. Dengan adanya kemudahan berkomunikasi tersebut, dapat dimanfaatkan dengan kemajuan teknologi berupa jejaring sosial media yang ada. Selain itu, secara internal memiliki ikatan emosional yang kolegial antara dosen sehingga tidak adanya unsur senioritas antara dosen yang telah lama menjabat dengan yang baru menjabat sebagai dosen di lingkungan Manajemen Dakwah UIN Suka Yogyakarta. Dalam pola komunikasinya, antara dosen dengan dosen memiliki grup tersendiri, antara jurusan dengan mahasiswa melalui akun Instagram Sunan Kalijaga sebagai pengelolanya ketua Jurusan sendiri sehingga jika ada informasi yang berasal dari jurusan disampaikan kepada mahasiswa dalam satu komando lewat akun media sosial tersebut. ${ }^{29}$

Sebagai seorang pemimpin di Program Studi Manajemen Dakwah, ketua jurusan haruslah senantiasa memberikan motivasi kepada para dosen dalam meningkatkan kinerja dan kapasitas dirinya. Dalam memotivasi para dosen, ketua jurusan perlunya menanamkan nilai

${ }^{29}$ Hasil wawancara dengan Bapak Aris Risdiana, S.Sos.I., M.M. selaku Sekretaris Jurusan Prodi Manajemen Dakwah, Tanggal 29 November 2019, pukul 13.05 WIB. 
spiritual antara lain dengan mengaitkan segala aktivitas dan kegiatan di kampus sebagai bentuk ibadah kepada Allah bahwasanya setiap kebaikan pasti akan kembali kepada yang berbuat kebaikan, setiap kebaikan yang dilakukan mendatangkan kebahagiaan dan Allah pasti membalas kebaikan yang dilakukan dengan balasan berlipat ganda pula.

Salah satu bentuk ketua jurusan memotivasi para dosen ialah dengan cara senantiasa mendorong dosen yang belum meraih gelar doctor agar segera menyelesaikan kuliah doktoralnya sebagai syarat dapat membuka program studi S2 Manajemen Dakwah di UIN Sunan Kalijaga Yogyakarta di tahun 2021 tersebut.

Adapun bentuk kepemimpinan spiritual lainnya yang telah diterapkan di program studi dapat terlihat dari bagaimana program studi memegang teguh prinsip keadilan, sebagaimana yang telah dicontohkan oleh Nabi Muhammad saw. Praktik keadilan yang berjalan di program studi ini ialah dengan adanya sistem pemberian reward (penghargaan) dan juga punishment (hukuman) yang dilakukan secara objektif tanpa dibeda-bedakan. Dalam praktiknya, ketua Jurusan memberikan penghargaan kepada para dosen yang berprestasi sebagai bentuk dedikasi dan loyalitasnya bagi program studi. Bentuk pemberian penghargaan ini berupa memberikan pemahaman bahwa setiap perbuatan baik akan selalu mendapatkan balasan Allah. Selain itu, reward yang diberikan oleh Ketua Jurusan ialah berupa sejumlah materi yang sudah disiapkan. Reward ini ditujukan kepada dosen-dosen yang mau berpartisipasi dengan hal-hal bermanfaat bagi kemajuan program studi. Di samping itu pula, reward ketua jurusan dengan pemberian apresiasi berupa bentuk selamat dalam bentuk spanduk atau baligho kepada dosen yang telah menyelesaikan studinya.

Di samping adanya pemberian reward, ketua jurusan juga menerapkan sistem pemberian punishment. Sejauh ini, punishment dilakukan sebagai bentuk teguran bagi para dosen yang sekiranya lalai dari tugasnya dan sulit ditemui mahasiswanya. Salah satu bentuk punishment yang diterapkan di program studi ini ialah pengurangan jatah sebagai dosen pembimbing skripsi untuk mahasiswa tingkat akhir.

Praktik penegakan keadilan tidak hanya berlaku untuk jajaran dosen, namun pula berlaku untuk para mahasiswa yang telah melanggar peraturan di program studi. Bentuk praktik keadilan dan kedisiplinan yang diterapkan pada mahasiswa ialah dengan ketentuan masuk pukul 07.00 WIB dengan batas toleransi 15 menit dengan ketentuan kurang 1 menit tidak diperbolehkan mengikuti proses pembelajaran di kelas. Hal ini tidak hanya berlaku untuk mahasiswanya saja, namun juga diberlakukan oleh ketua jurusannya tersendiri di saat jam pelajaran perkuliahannya. 
Dalam praktiknya, untuk membina kedisiplinan di Program Studi, Ketua Jurusan senantiasa memberikan contoh dengan senantiasa hadir lebih awal daripada dosen yang lain. Hal ini dilakukan sebagai bentuk keteladanan ketua jurusan sebagai seorang pemimpin di ranahnya program studi. Ketua Jurusan menjadi contoh bagi para dosen bahwasanya keteladanan perlunya dimulai dari pemimpinnya. Artinya,tidaklah adil jika menuntut mahasiswa untuk berperilaku disiplin apabila tidak dimulai terlebih dahulu oleh dosen dan ketua jurusannya.

Selain hal itu, ditilik dari segi proses pengambilan keputusan, ketua jurusan menerapkan dan menjunjung tinggi musyawarah berasaskan mufakat. Musyawarah ini dilakukan dengan melibatkan seluruh pihak yang ada di jurusan dalam pengambilan sebuah keputusan dan kebijakan yang berskala besar atau musyawarah bidang terkait (seperti sarana dan prasarana atau administrasi) untuk mengambil sebuah kebijakan tertentu.

Dalam kepemimpinan spiritual ini, sosok yang dijadikan sebagai inspirasi utama ialah kepemimpinan yang ditunjukkan oleh figur seorang Nabi Muhammad saw. Setidaknya terdapat empat sifat utama yang dimiliki oleh Nabi Muhammad saw antara lain sidiq (benar), amanah (dapat dipercaya), tabligh (menyampaikan), serta fathanah (cerdas). Sifat inilah yang kemudian menjadi value, acuan utama, keteladanan, serta pedoman bagi ketua jurusan dalam mengemban amanah dan melaksanakan tugasnya.

Praktik peneladanan sifat-sifat nabi seperti sifat Sidiq (jujur) yaitu ketua jurusan selalu menyampaikan sesuatu apa adanya kepada dosen maupun personil stakeholder lainnya. Hal ini terkait seperti trasnparansi penggunaan anggaran program studi yang ada di jurusan Manajemen Dakwah. Sedangkan bentuk peneladanan sifat amanah dilakukan dengan berupaya semaksimal mungkin dalam menjaga kepercayaan terhadap kemajuan program studi. Upaya maksimal dan sungguh-sungguh dikerahkan untuk mengoptimalkan perkembangan jurusan. Adapun peneladanan sifat tabligh dilakukan dalam bentuk transparansi dan keterbukaan terkait kebijakan keuangan maupun kebijakan lainnya. Selain itu, peneladanan sifat fathanah Nabi dilakukan dengan senantiasa mencari tantangan dalam sebuah pembaharuan dan kemajuan, serta mengerahkan kecerdasan serta potensi masing-masing individu maupun kelompok untuk senantiasa bergerak dinamis bagi kemajuan program studi.

Beranjak dari kepemimpinan spiritual yang diterapkan oleh Bapak Drs. Rosyid Ridla, M.Si selaku Ketua Jurusan Manajemen Dakwah maka berbagai kebijakan diterapkan terhadap kemajuan dan perkembangan program studi manajemen dakwah. Tentunya hal ini berkaca dari maqashid Syariah yang mana menjunjung kemaslahatan Bersama dan menghilangkan kemafsadatan. Kebijakan yang diterapkan oleh Ketua Jurusan Program Studi Manajemen 
Dakwah bertujuan agar program pembinaan spiritual tidak hanya dilakukan untuk kemaslahatan para dosen saja akan tetapi juga berdampak kepada para mahasiswa khususnya yang berada di Program Studi Manajemen Dakwah. Kebijakan-kebijakan tersebut tidaklah terlepas dari kebijakan spiritual yang merujuk kepada keteladanan Rasulullah saw.

Salah satu kebijakan Ketua Jurusan dalam bidang Hifdzu 'Aql (penjagaan akal) ialah dengan diterapkannya mata perkuliahan tahfidzul Qur'an yang semulanya 0 sks menjadi bobot 2 sks sebagai penunjang para mahasiswa agar terbiasa untuk hafal juz 30 beserta surat surat pilihan lainnya. Untuk pembinanya melibatkan para alumni yang telah memiliki hafalan. Program mata kuliah ini sudah berlaku semenjak 2 tahun yang lalu pada mahasiswa semester 7. Hal ini tentu saja memiliki dampak kedepannya agar ilmu yang sudah dipelajari oleh mahasiswa dapat diamalkan dan menjadi bekal di dunia dan akhirat. Selain itu, dalam setiap kelasnya tersedia pula kelas tambahan berupa BTHQ (Baca Tulis Hafalan Qur'an) diluar kurikulum perkuliahan mata pelajaran Islam yang telah disepakati.

Bentuk kebijakan lainnya pula, tampak dari Laboratorium di Manajemen Dakwah merupakan satu-satunya di UIN Sunan Kalijaga Yogyakarta program studi yang mempunyai perpustakaan sendiri. Hal ini sebagai referensi para mahasiswanya agar memudahkan dalam literasi terkait program studi manajemen dakwah. Di dalam perpustakaannya terdapat berbagai skripsi dan buku yang telah dihibahkan oleh para alumni Manajemen Dakwah.

Gambar 1. Perpustakaan Program Studi Manajemen Dakwah

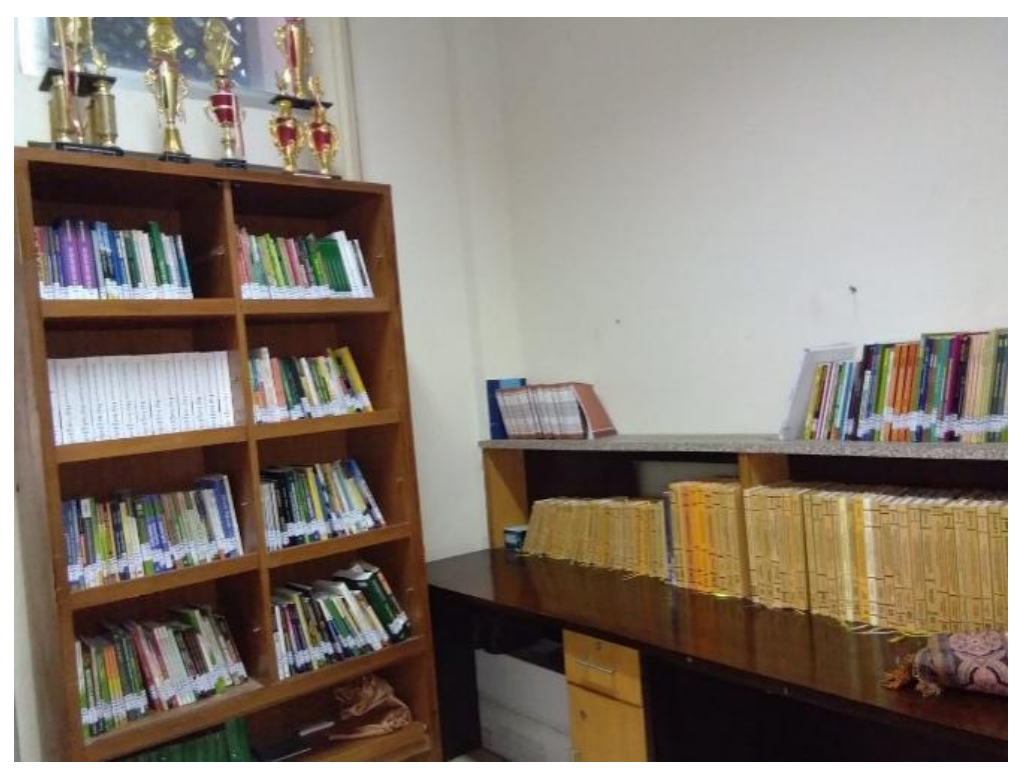

Selain itu, kebijakan yang diterapkan oleh ketua jurusan dalam bidang Hifdzu 'Mal (penjagaan harta) ialah dengan diadakannya Baitul Maal wa Tamwil (BMT) sebagai miniatur lembaga keuangan serta penunjang karir dalam proses pembelajaran bagi mahasiswa Manajemen Dakwah khususnya konsentrasi Manajemen Lembaga Keuangan Islam. Di dalam 
BMT ini, siapapun berhak untuk menabung dan meminjam uang kepada lembaga ini dan tidak terkecuali hanya mahasiswa Manajemen Dakwah saja. Selain itu, Prodi Manajemen Dakwah ini juga telah memiliki ruangan khusus sendiri Baitul Maal wa Tamwil untuk mengadakan proses transaksi simpan-pinjam. Selain itu pula, kebijakan lainnya dari berbagai perguruan tinggi yang ada, hanya beberapa perguruan tinggi keagamaan yang sudah dapat menyelenggarakan uji sertifikasi dan diberikan otoritas untuk melakukan sertifikasi di Indonesia atau kerja sama dalam program manasik haji. Setelah memperoleh sertifikasi haji di bulan April, maka tawaran kerjasama di tanggal 8-15 Desember 2019 bekerjasama dengan Kementerian Agama Kantor Wilayah Yogyakarta.

Gambar 1.2. Baitul Maal wa Tamwil Prodi Manajemen Dakwah

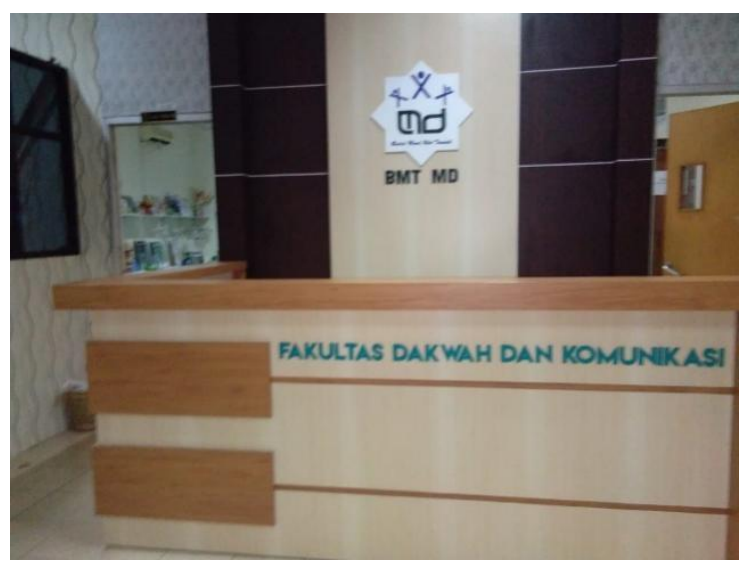

Adapun kebijakan yang berkaitan dengan Hifdzul Din (penjagaan agama) ialah secara tidak langsung melaksanakan rihlah ilmiah atau kunjungan lembaga industri dengan melakukan ziarah ke makam para wali sebagai bagian dari Mata Perkuliahan. Kebijakan ini diterapkannya Mata Kuliah Manajemen Wisata Keagamaan di semester genap pada setiap tahunnya dengan cara diperkenalkan dengan situs keislaman lokal di kota Yogyakarta. Selain itu pula, kebijakan lainnya dengan adanya program dosen keagamaan di fakultas dengan dirutinkannya untuk mengikuti tadarus Al-Qur'an di setiap Jum'at pagi sekaligus KULTUM (Kuliah Tujuh Menit) di setiap bulan Ramadhan.

Selain itu pula, kebijakan ketua jurusan dalam maqashid Syariah bidang hifdzu Nasl (penjagaan keturunan) ialah dengan diadakannya organisasi mahasiswa yang melaksanakan kegiatan keagamaan seperti pentas seni mahasiswa, hadrahan, orientasi mahasiswa baru dengan jalannya pengkaderan dari program studi Manajemen Dakwah.

Berbeda halnya dengan kebijakan lainnya yaitu hifdzu Nafs (Penjagaan Diri) dengan diberlakukannya peraturan bahwasanya apabila terdapat mahasiswa yang hendak masuk ke program studi dilarang menggunakan jeans dan segala bentuk bimbingan atau keperluannya 
tidak akan diterima oleh Program Studi. Hal ini menunjukkan bentuk kedisiplinan terhadap mahasiswa yang diterapkan oleh program studi.

\section{Kesimpulan}

Berdasarkan pemaparan di atas, dapat ditarik kesimpulan bahwasanya kepemimpinan spiritual disini ialah cara mempengaruhi orang lain untuk tercapainya suatu tujuan tertentu melalui perbuatan yang bernilai. Dalam Islam, Nabi Muhammad saw sebagai sosok inspirasi dalam menjalankan praktik kepemimpinannya. Beberapa ciri penting yang menggambarkan kepemimpinan spiritual ialah setia, maksud setia disini bermakna bahwasanya seorang pemimpin dan orang yang dipimpin haruslah setia kepada Allah swt, terkait tujuan, menjunjung tinggi syariat dan akhlak Islam, memegang teguh amanah, tidak sombong, disipin, konsisten, serta memiliki karakter yang konsekuen.

Implementasi kepemimpinan spiritual di Program Studi Manajemen Dakwah Fakultas Dakwah dan Komunikasi UIN Sunan Kalijaga Yogyakarta yaitu adanya penanaman nilai-nilai yang tidak hanya berorientasi pada kehidupan di dunia semata, melainkan juga kehidupan di akhirat. Oleh karenanya, ketua jurusan serta para dosen dalam menjalankan tugasnya tidak hanya sebatas menggugurkan kewajiban administrasi dan pengajaran semata, namun juga sebagai bentuk sarana pengabdian kepada Allah swt. Implementasi kepemimpinan spiritual di program studi tersebut, juga dipraktikkan dengan meneladani sifat kepemimpinan yang dicontohkan Nabi Muhammad saw, diantaranya komunikasi yang baik antara ketua jurusan dan anggotanya, kepala jurusan menjadi sebagai motivator, adil, jujur, amanah, musyawarah, serta menerapkan prinsip kedisiplinan.

Dari pembahasan di atas dapat ditarik kesimpulan, bahwasanya pembicaraan mengenai maqashid syari'ah atau tujuan hukum Islam merupakan suatu pembahasan penting yang tiada luput dari perhatian ulama serta pakar hukum Islam. Bila ditelaah, semua perintah dan larangan Allah swt dalam Al-Qur'an serta suruhan dan larangan Nabi Muhammad saw dalam Hadits tampaklah jelas bahwasanya segala sesuatu aturan ataupun kebijakan yang ditetapkan pastinya memiliki tujuan tertentu yang tidak akan sia-sia dan mempunyai kemaslahatan didalamnya. Maqashid syari'ah ialah maksud Allah selaku pembuat syari'at untuk memberikan kemaslahatan kepada manusia yaitu dengan harus terpenuhinya kebutuhan pertama, dlaruriyah (primer) dimulai dari sisi hifdz al-din (pemeliharaan agama) yang mencakup adanya kunjungan lembaga industri dalam mata perkuliahan dengan bentuk ziarah makam wali serta dirutinkannya tadarus Al-Qur'an di setiap Jum'at pagi pada bulan Ramadhan, hifdz al-nafs (pemeliharaan jiwa) dengan bentuk peraturan tidak diperkenankan mahasiswa menggunakan 
celana jeans di sekitar program studi Manajemen Dakwah baik untuk keperluan akademik atau lainnya, hifdz al-aql (pemeliharaan akal) dengan bentuk diterapkannya Mata Kuliah Tahfidz Al-Qur'an di semester akhir, kelas tambahan BTHQ (Baca Tulis Hafidz Qur'an) serta pengadaan perpustakaan program studi tersendiri untuk menunjang keperluan akademik. Hifdz al-nasl (pemeliharaan keturunan) dengan cara monitoring organisasi mahasiswa yang mengadakan kegiatan keagamaan serta pengkaderan mahasiswa baru di program studi dan hifdz al-maal (pemeliharaan harta) dalam bentuk pengadaan Baitul maal wa tamwil sebagai upaya bimbingan karir mahasiswa Program Studi Manajemen Dakwah. Dalam beberapa kebijakan ini tentunya bermaksud agar tercapainya kemaslahatan dunia dan akhirat dengan tetap mengedepankan kepemimpinan spiritual yang diterapkan oleh Ketua Jurusan Prodi Manajemen Dakwah. 


\section{Daftar Pustaka}

Al-Hufy, Ahmad Muhammad, Akhlak Nabi Muhammad SAW: Keluhuran dan Kemuliannya, Alih Bahasa. Masdar Hilmy, Bandung: Gema Risalah Press, 1995.

Auda, Jaser, Membumikan Hukum Islam Melalui Maqasid Syariah, Bandung: PT Mizan Pustaka, 2015.

Fauzia dan Riyadi A, Prinsip Dasar Ekonomi Islam Perspektif Maqashid Al- Syari'ah, (Jakarta: Kencana Prenadamedia Group, 2014.

Febriadi, Sandy Rizki “Aplikasi Maqashid Syariah Dalam Bidang Perbankan Syariah”, Jurnal Amwaluna, Vol. 1, No 2, Juli 2017.

Ishak, Model Kepemimpinan Etika Berlandas Sirah Nabi Muhammad SAW., Jurnal Hadhari 3, 2 2011, Universiti Kebangsaan Malaysia.

Jamaa, La, "Dimensi Ilahi dan Dimensi Insani dalam Maqashid al-Syari'ah". Jurnal AsySyir'ah Ilmu Syari'ah dan Hukum, Vol 45, No. II, Juli-Desember 2011.

Mawardi, Ahmad Imam, Fiqh Minoritas Fiqh Al-Aqalliyat dan Evolusi Maqashid Al-Syari'ah model Konsep ke Pendekatan), Yogyakarta: PT LKiS Printing Cemerlang, 2012.

Mulyasa, Manajemen dan Kepemimpinan Kepala Sekolah, Jakarta: Bumi Aksara, 2012.

Prastowo, Andi, Metode Penelitian Kualitatif, Yogyakarta: Ar-Ruzz Media, 2014.

Mulyana, Deddy, Metodologi Penelitian Kualitatif, Bandung: PT Remaja Rosdakarya, 2010.

Mutakin, Ali, "Teori Maqashid Al Syariah dan Hubungannya dengan Metode Istinbath Hukum”, Jurnal Ilmu Hukum, Vol 19, No 3, Agustus 2017.

Rahmi, Nispan, "Maqasid Al Syari'ah: Melacak Gagasan Awal”. Jurnal Ilmu Hukum dan Pemikiran Maqasid al-Syari'ah, Vol 17, No 2, Desember 2017.

Rivai, Veithzal, dan Arifin, Arviyan, Islamic Leadership: Membangun Superleadership Melalui Kecerdasan Spiritual (Jakarta: Bumi Aksara, 2009.

Shidiq, Ghofar, “Teori Maqashid Al-Syariah dalam Hukum Islam”. Jurnal Majalah Ilmiah Sultan Agung, Vol 44, No 118, Juni-Agustus 2009.

Syamsudin, Tesis Magister: "Kepemimpinan Profetik: Telaah Kepemimpinan Umar bin Khattab dan Umar bin Abdul Aziz”, Malang: UIN Maulana Malik Ibrahim, 2015.

Thahir, Halil, Ijtihad Maqasidi (Rekonstruksi Hukum Islam Berbasis Interkoneksitas Maslahah, Yogyakarta: PT LKiS Printing Cemerlang, 2015.

Wibowo, Kepemimpinan: Pemahaman Dasar, Pandangan Konvensional, Gagasan Kontemporer Jakarta: Rajawali Pers, 2016. 
Nur Ita A'ini Qudwatal Millah, Far'ia

Yusuf, A. Muri, Metode Penelitian Kuantitatif, Kualitatif, dan Penelitian Gabungan, Jakarta: Kencana, 2015.

Zaini, Subarto, Leadership in Action: Pembelajaran dari Para Maestro (Jakarta: PT. Elex Media Komputindo, 2011. 